Gut, 1972, 13, 535-538

\title{
Immunoglobulin-containing cells in the small intestine during acute enteritis
}

\author{
J. SøLTOFT¹ AND B. SøEBERG \\ From the University Clinic of Infectious Diseases, Copenhagen, the Medical Department, \\ Blegdamshospitalet, Copenhagen, and the Medical Department B, Gentofte Amtssygehus, Copenhagen
}

SUMMARY Jejunal mucosal biopsies were obtained from 13 patients with acute enteritis. Ten patients were examined again after recovery. Quantitative analysis of the findings in immunofluorescence microscopy showed a significant increase of $\operatorname{IgA-}$ and IgM-containing cells during acute enteritis. After recovery the number of immunoglobulin-containing cells and their distribution within the different immunoglobulin classes were within normal limits.

The lamina propria of the gastrointestinal tract is richly endowed with immunoglobulin-containing cells. These are considered to participate in local immune defence and to produce the major part of the immunoglobulins found in external secretion.

To assess the influence of naturally occurring antigen stimulation on the immunoglobulin-containing cells of the human intestine the following study was carried out. Jejunal biopsies from patients with acute enteritis were obtained during the acute period and after recovery and the number of immunoglobulin-containing cells and theirdistribution on the different immunoglobulin classes were quantitated.

\section{Material}

Thirteen patients, who were aged 17 to 70 years (median 39 years), with acute enteritis, all had fever and at least 15 watery, malodorous bowel movements a day without blood contamination. The diarrhoea persisted for five to 22 days (median eight days) and was the primary cause of hospital admission. In four cases salmonellae were cultured from the stools but in the remaining cases repeated bacteriological examinations were negative. All the patients were living in Denmark but eight had encountered the disease during tourist travel in southern Europe. None had previously had gastrointestinal complaints. except two who had had the gallbladder removed some years before because of gallstones. All patients

${ }^{1}$ Requests for reprints should be addressed to: J. Søltoft, Medical Department B, Amtssygehuset i Gentofte. DK-2900 Hellerup, Denmark.

Received for publication 4 May 1972. recovered spontaneously and except for intravenous fluid no treatment was given.

Jejunal mucosal biopsies were obtained seven to 30 days after the onset of the diarrhoea, usually a few days (median two days) after the diarrhoea had ceased.

The patients were examined again after at least three months of recovery. None then had gastrointestinal complaints and in 10 cases repeat biopsies were obtained.

\section{Biopsy Specimen Material}

The jejunal mucosal biopsies were obtained with a peroral suction biopsy tube. The localization was controlled by fluoroscopy and multiple biopsies were taken at the same level. Biopsies for immune fluorescence studies were immediately frozen and stored over dry ice. Thestereomicroscopic appearance of other biopsies was evaluated before light microscopic examination.

\section{Antisera}

Details of the preparation and labelling of antisera with fluorescein-isothiocyanate have been fully described elsewhere (Søltoft and Søeberg, 1972). Optical density ratios expressing $E_{495}^{\prime}: E_{282}^{\prime}$ ranged between 0.3 and $\mathbf{0 \cdot 8}$. Protein concentration at working dilution ranged between 0.2 and $1.5 \mathrm{mg} / \mathrm{ml}$. The antisera were tested against normal human serum, myeloma proteins, and kappa and lambda Bence-Jones protein at different concentrations. Anti-IgA, -IgG, and -IgM were tested against bone marrow samples from patients with IgG or IgA 
myeloma or against splenic sections from a patient with macroglobulinaemia. Anti-'secretory piece' reacted only with free and bound secretory piece when tested against whole colostrum. When antisecretory piece was tested against one of the fractions from DEAE-Sephadex chromatography of colostrum an additional weak reaction with an $\alpha_{2}$-component was demonstrated. This $\alpha_{2}$-component was not due to lactoferrin.

\section{Fluorescence Microscopy}

The technique of fluorescence microscopy and quantitative analysis of the mucosal sections has been described elsewhere. The area of cells in lamina propria containing each immunoglobulin was measured by planimetry, and was related to the total area of lamina propria. The values calculated in this study were compared with the normal values for immunoglobulin-containing cells described previously (Søltoft and Søeberg, 1972). Each calculation was based on planimetry of at least 10 visual fields. Repeated quantitation of the immunoglobulincontaining cells revealed a coefficient of variation of less than $0 \cdot 17$. To reduce observer bias the quantitation procedure was carried out without knowledge of the identity of the biopsies.

\section{Results}

The stereomicroscopic appearance was abnormal in one case where areas of subtotal villus atrophy were found during the acute phase. Light microscopic examination revealed heavy cellular infiltration in this and in another biopsy that appeared normal in the stereomicroscope. In both cases normal mucosal appearances were found when repeat biopsy was taken after recovery. In the remaining cases no major alterations were seen.

Immunofluorescence microscopy showed fluorescence of mononuclear cells in lamina propria in patients with acute enteritis. With anti-IgA fluorescence of the luminal end of the enterocytes was seen in addition to the fluorescence of cells in the lamina propria. No fluorescence of lymphocytes in the epithelium was seen with any of the antisera.

The cells giving fluorescence could morphologically be classified as plasma cells although a greater number than usual were minor cells with a less abundant cytoplasm. The intestinal tissue gave a stronger background staining with anti-IgA, $-\operatorname{IgM}$, and $-\operatorname{IgG}$ than usual although the background staining was not as intense as in patients with untreated sprue.

With anti-'secretory piece' an altered staining pattern was seen. Fluorescence of the complete cytoplasm of the enterocyte was found whereas only the luminar end is stained in normal conditions. This was most pronounced at the tip of the villus but was not present in all areas of a biopsy. This staining pattern was observed in eight of the patients during acute enteritis but in none examined again after recovery.

Quantitation of the areas of immunoglobulincontaining cells revealed (Table I) the following mean value and standard deviations (2 SD).

The IgE-containing cells were not quantitated because of their very limited number.

The area of IgA-containing cells was significantly increased (Willcoxon rank sum test) (Fig. 1) during enteritis when compared with controls $(\mathrm{P}<0.01)$ $(\operatorname{IgA}, 11 \cdot 3 \pm 5 \cdot 2 ; \operatorname{IgM}, 3.9 \pm 2 \cdot 6 ; \operatorname{IgG}, 1 \cdot 8 \pm 1 \cdot 2$; $\operatorname{IgD}, 1 \cdot 3 \pm 1 \cdot 0 ; \operatorname{IgE}<0 \cdot 1)$ and to the period after

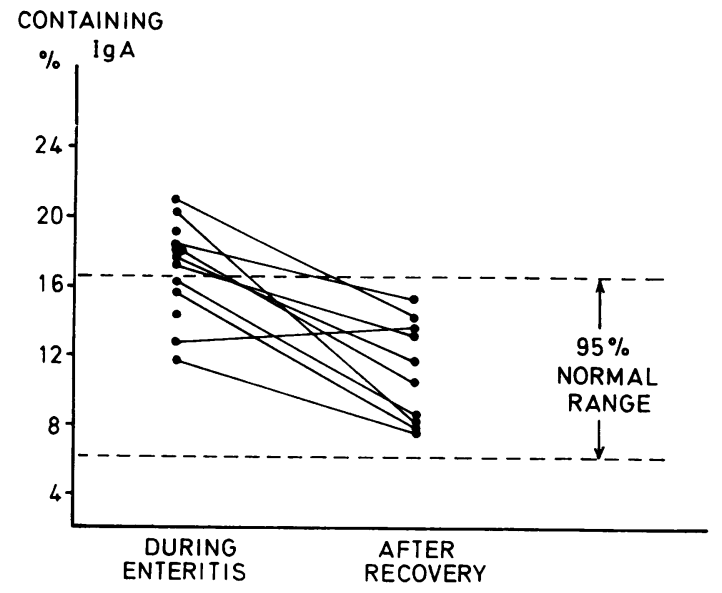

Fig. 1 IgA-containing cells as a percentage of interstitial tissue during enteritis and after recovery.

\begin{tabular}{lllll}
\hline & $I g A$ & $I g M$ & $I g G$ & $I g D$ \\
\cline { 2 - 5 } During enteritis & $17.0 \pm 5.4$ & $5.1 \pm 2.6$ & $2.0 \pm 1.6$ & $1.1 \pm 0.8$ \\
After recovery & $11.1 \pm 5.2$ & $\mathbf{3 . 5} \pm \mathbf{1 . 6}$ & $\mathbf{2 . 1} \pm \mathbf{1 . 2}$ & $1.3 \pm \mathbf{0 . 8}$ \\
\hline
\end{tabular}

Table Area of immunoglobulin-containing cells as percentage of intestinal area during acute enteritis and after recovery 


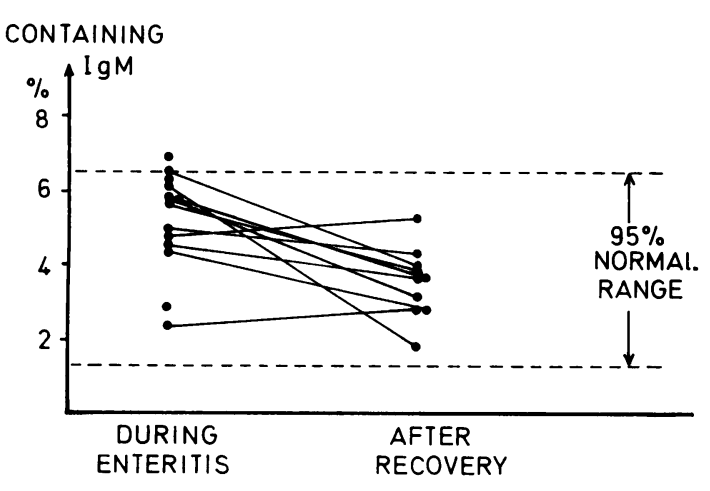

Fig. 2 IgM-containing cells as a percentage of interstitial tissue during enteritis and after recovery.

recovery $(\mathrm{P}<0.01)$ when no difference could be found between the patients and the controls (P > 0.1). The increase of IgM-containing cells (Fig. 2) was also significant when compared with the period after recovery $(P<0.01)$ and to the controls $(P<0.05)$. After recovery no difference could be found between patients and controls according to the content of $\operatorname{IgM}$ cells $(P>0 \cdot 1)$. The area of IgG- and IgD-containing cells was not significantly altered in the enteritis group neither during nor following acute enteritis.

\section{Discussion}

Jejunal mucosal biopsies in 13 patients with acute enteritis failed to exhibit any specific or notable abnormality under light microscopic or stereomicroscopic examination. Minor morphological abnormalities that disappeared during recovery were seen in two patients in whom the aetiology of the enteritis was not known. These findings are in accordance with recent reports on the proximal small bowel morphology during acute enteritis. Chuttani, Jain, and Misra (1971) in their study of 22 patients with typhoid fever found only minor mononuclear cell infiltration in eight patients, an abnormality frequently seen in populations of the tropics (Russell, Aziz, Ahmad, Kent, and Gangarosa, 1966; Lindenbaum, Alam, and Kent, 1966). Sprinz, Gangarosa, Williams, Hornick, and Woodward (1966) in their study of experimental human typhoid fever found a granulomatous enteritis in small-bowel biopsies obtained shortly after challenge. However, repeat biopsies taken at a time corresponding to the first biopsies obtained in our study showed only minor mononuclear cell infiltration. Similarly unspecific mucosal mononuclear infiltration has been found in other infections involving the gastrointestinal tract, as for instance clinical and experimental cholera (Gangarosa, Beisel, Benyajati, Sprinz, and Piyaratn, 1960; Fresh, Versoge, and Reyes, 1964), giardiasis (Barbieri, De Brito, Hoshino, Nascimento, Campos, Quarentei, and Marcondes, 1970), viral hepatitis (Astaldi, 1969; Conrad, Schwarts, and Young, 1964), and certain viral diseases (Sheehy, Arenstein, and Green, 1964).

The quantitative measurements of the immunoglobulin-containing cells in the jejunal mucosa revealed a grossly unchanged pattern with predominance of $\operatorname{IgA}$ and the usual sequence $\operatorname{IgA} \gg$ IgM $\gg$ IgG $>$ IgD $\gg$ IgE. However, in biopsies obtained during or immediately after acute enteritis a significant increase of IgA cells and a minor increase in IgM cells was found.

IgA has for some years been known to be the quantitatively most important mucosal immunoglobulin in man and in all species investigated (Vaerman, 1970). Both among the mucosal immunocytes (Crabbé, Carbonara, and Heremans, 1965) and secretory immunoglobulins (Tomasi, Tan, Solomon, and Prendergast, 1965) IgA predominates. The major part of IgA at the human gastrointestinal surfaces occurs as secretory IgA build up of dimeric IgA combined with two minor proteins-'secretory piece' and 'J-chain'. Recent studies have confirmed the protective value of secretory-IgA (Bellanti, Smith, Kim, Mills, Gerin, Parrott, and Chanock, 1971), and several animal experiments have shown that oral immunization increases the mucosal IgAcontaining cells (Crabbé, Nash, Bazin, Eyssen, and Heremans, 1969; Felsenfeld, 1970). Thus, the increase in $\operatorname{IgA}$-containing cells following acute enteritis found in this study is not surprising. However, the magnitude of this reaction was impressive. The increase of $\operatorname{IgA}$ cells during acute enteritis was on an average $50-60 \%$. The true figure might even be higher because some oedema seems to be present in some of the biopsies obtained during acute enteritis. Although no conclusions can be drawn concerning the dynamics, the immunofluorescence microscopic picture is most suggestive of intense antibody production. The reaction is remarkably strong if it is elicited only by challenge with a few antigens. However, as the specificity of this antibody response is not known it cannot be excluded that it is directed against a wide range of antigens. It is not unlikely that the agent inducing the enteritis damages the epithelium so that the immunocytes are presented to ordinarily contracted luminal antigens at a concentration and at a site that elicits production of antibody on a wide scale.

This study was supported by grants from the Danish Medical Research Council. 
References

Astaldi, G. (1969). Histological observations in normal and pathologic jejunal biopsy specimens. Acta anat., 73, Suppl. 56, 40-59.

Barbieri, D., De Brito, T., Hoshino, S., Nascimento, O. B., Campos, J. V. M., Quarentei, G., and Marcondes, E. (1970). Giardiasis in childhood. Arch. Dis. Childh., 45, 466-472.

Bellanti, J. A., Sinith, C. B., Kim, H. W., Mills, J., Gerin, J. L., Parrott, H. R., and Channock, R. M. (1969). Serum and local respiratory antibody responses following infections with 'mycoplasma pneumonia' or respiratory syncytial virus. In The Secretory Immunologic System, pp, 183-194. U.S. Government Printing Office, Washington, D.C.

Chuttani, H. K., Jain, K., and Misra, R. C. (1971). Small bowel in typhoid fever. Gut, 12, 709-712.

Conrad, M. E., Schwartz, F. D., and Young, A. A. (1964). Infectious hepatitis-a generalized disease. Amer. J. Med., 37, 789-801.

Crabbé, P. A., Carbonara, A. O., and Heremans, J. F. (1965). The normal human intestinal mucosa as a major source of plasma cells containing $\gamma$ A-immunoglobulin. Lab. Invest., 14, 235-248.

Crabbé, P. A., Nash, D. R., Bazin, H., Eyssen, H., and Heremans, J. F. (1969). Antibodies of the IgA type in intestinal plasma cells of germfree mice after oral or parenteral immunization with ferritin. J. exp. Med., 130, 723-744.

Felsenfeld, O. (1970). Standardization of the measurement of cell bound antibody responses in enteric infections. Progr. immunobiol. Stand., 4, 312-315.
Fresh, J. W., Versage, P. M., and Reyes, V. (1964). Intestinal morphology in human and experimental cholera. Arch. Path., 77, 529-537.

Gangarosa, E. J., Beisel, W. R., Benyajati, C., Sprinz, H., and Piyaratn, P. (1960). The nature of the gastrointestinal lesion in Asiatic cholera and its relation to pathogenesis: a biopsy study. Amer. J. trop. Med., 9, 125-135.

Lindenbaum, J., Alam, A. K. M. J., and Kent, T. H. (1966). Subclinical small-intestinal disease in east pakistan. Brit. med. J., 2, 1616-1619.

Russell, P. K., Aziz, M. A., Ahmad, N., Kent, T. H., and Gangarosa, E. J. (1966). Enteritis and gastritis in young asymptomatic Pakistani men. Amer. J. dig. Dis., 2, 296-306.

Sheehy, T. W., Arenstein, M. S., and Green, R. W. (1964). Small intestinal mucosa in certain viral diseases. J. Amer. med. Ass., 190, 1023-1028.

Søltoft, J., and Søeberg, B. (1972). Immunoglobulin-containing cells in the small intestine in viral hepatitis. Acta path. microbiol. scand., in press.

Sprinz, H., Gangarosa, E. J., Williams, M., Hornick, R. B., and Woodward, T. E. (1966). Histopathology of the upper small intestines in typhoid fever. Amer. J. dig. Dis., 11, 615-624.

Tomasi, T. B., Tan, E. M., Solomon, A., Prendergast, R. A. (1965). Characteristics of an immune system common to certain external secretions. J. exp. Med., 121, 101-124.

Vaerman, J. P. (1970). Studies on IgA immunoglobulins in man and animals. Thesis, Department de Médicine Experimentale, Louvain. 